\title{
Spiritual Dimensions in Exploring the Human-Geosphere Relationship under a Values-Based Approach in Lake Turgoyak, Southern Urals, Russia
}

FRANCESC BELLAUBI

\begin{abstract}
Surrounded by mountains and forests, Lake Turgoyak in the Southern Urals (Russia) is a popular tourist destination. However, the many resorts and camps as well as the high number of visitors have had a negative environmental impact on the lake. Taking Lake Turgoyak as a case study, the research examines the values in the human-geosphere relationship, framed as a geoethical dilemma revisiting the concept of the noosphere. The formulation of geoethical dilemmas, as a way to explore the values that underpin the technocratic artifacts on which humans relate to the geosphere, reveals a spiritual dimension that shapes cultural identities that, in turn, unfold in eco-ideologies of resistance in hope.
\end{abstract}

Keywords: dilemmas, eco-resistance, geoethics, geosphere, Lake Turgoyak, noosphere

$\mathrm{L}$ ake Turgoyak is a small lake at the foot of the Southern Urals (figure 1); a sacred, megalithic, ancient place and a site of pilgrimage for the Old Orthodox Believers (staroobriadtsy), descendants of the Eastern Russian Orthodox Church. Called the "smaller brother" of Lake Baikal, Lake Turgoyak (Russ. Ozero Turgoyak) was the home of the Bashkir tribes, a witness to Russian mining colonies and host to a nearby Soviet missile factory. The lake is located in the Chelyabinsk province, bordering Europe and Asia. This is one of the highly developed industrial regions of Russia with main railways and automobile roads that connect the European and Asian parts of Russia. According to some investigations, the region is one of the most polluted in the whole country. ${ }^{1}$ 


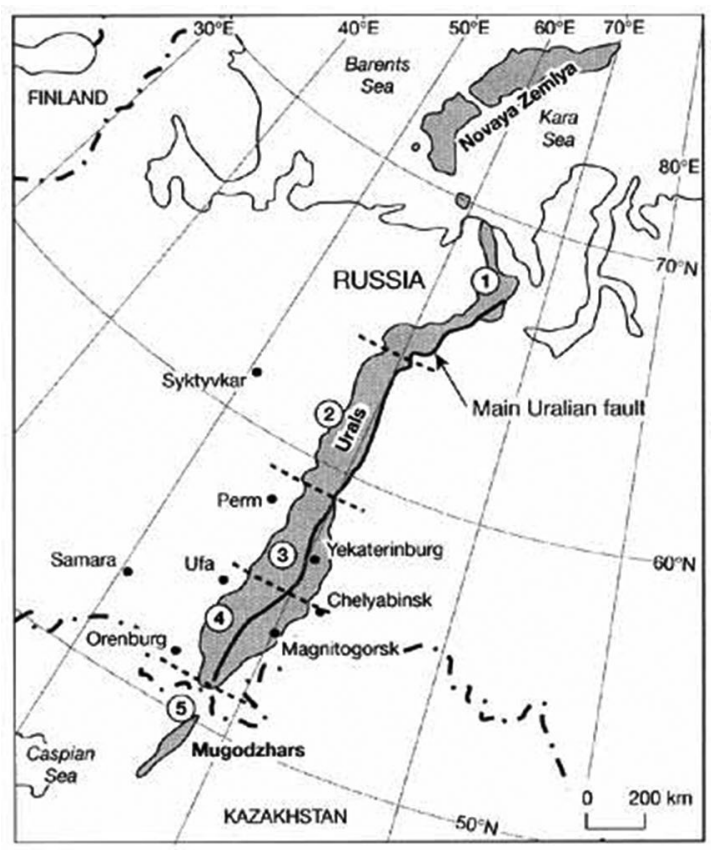

(1) North of $64^{\circ}$
Cis-Polar and Polar Urals

(2) $64^{\circ}-59^{\circ}$

Northern Urals

(3) $59^{\circ}-56^{\circ}$

Middle Urals

$56^{\circ}-51^{\circ}$

Southern Urals

South of $51^{\circ}$

Kazakh Urals and the

Mugodzhars

Figure 1. Map indicates the location of Lake Turgoyak in the Southern Ural Mountains between Ufa and Chelyabinsk. Source: "The Ural Mountains," n.d., http://www.rusnature.info/reg/13_3.htm.

Being around sixty million years old and formed during the Paleogene, Lake Turgoyak has an area of 26.4 square kilometers (width 6.3 $\mathrm{km}$ and length $6.9 \mathrm{~km}$ ) and is 34 meters in depth. The lake has no outflows because of the fall in the water level. The lake's recharge comes from both runoffs and hydrogeological recharge, but the ground flows are unknown. Lake Turgoyak is known for high-water visibility, which reaches twelve to nineteen meters (being the second clearest lake in Russia, after the Baikal). The water contains practically no mineral salts, leaving it soft; it has medicinal properties because of radon springs in the area. Weisberg and Zakharov (2001) documented the outstanding biodiversity around Lake Turgoyak.

Close to the Mashgorodok neighborhood of Miass city and to the small village that takes its name, Lake Turgoyak is a popular tourist destination with many resorts and camps; the annual number of tourists reaches 3.5 million, with peak visiting times in the summer season. The area has poor infrastructure: the roads are narrow, and there are 


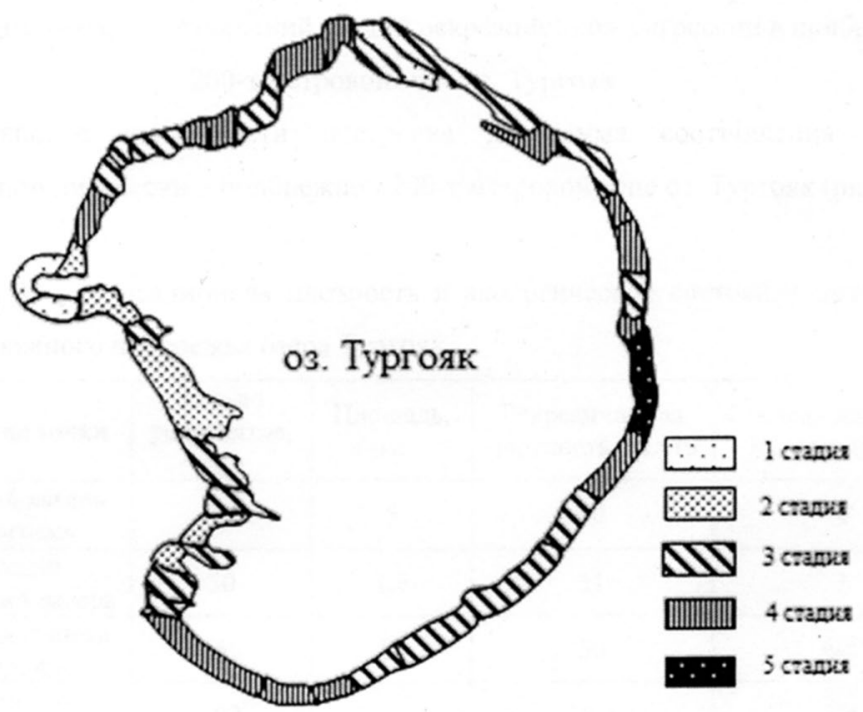

Figure 2. Map shows the degree of anthropogenic transformation on the coastal areas of Lake Turgoyak, with levels from one min to five max because of the recreational activities. Source: Lagunov 2019.

no parking places; some summer camps have problems with sewage or organized garbage disposal; the public beaches' water and shores are heavily polluted (figure 2). The private citizens undertake the construction of resorts and holiday homes near the lake and close to its shores, causing a considerable negative environmental impact on the landscape (Lagunov 2005).

This situation makes it evident that the challenges faced by the lake and by its inhabitants are not separate but rather an ecological one is nuclear (Francis 2015, Jesuit Social Services 2018; Nasr 1997) that puts the values in how humans relate to nature at stake. Although a value-based approach has been largely ignored on natural resource governance issues (Glenna 2010), a fundamental issue remains in considering the intrinsic value of nature; the value of nature in itself rather than what we do with it (value of use or value of exchange) (Kovel 2007), and which largely depends on how humans relate to each other in profiting from nature.

Environmental and social-related challenges rely on technology, but technology is not enough to tackle ecological problems because these problems involve the values in the human-nature relationship, which 
refer to how humans relate among themselves and the ethics that determine the core of these relationships (Bellaubi 2020; Kortetmäki 2017). Paradigms are based on archetypal values that define how we interpret and understand the world (our worldview) and, subsequently, justify our attitude (Kuhn 1970; Riechmann et al. 2019). The current development paradigm of Technopoly (Postman 1993) relies on a technocratic political and economic status quo and is sustained by the existing and highly specialized educational system ${ }^{2}$ that has negative impacts on society, as argued by Ortega y Gasset (Delgado 2010), and where nature is seen as a resource under utilitarian-instrumental values ("to profit from" or, apparently less damaging, "to make sustainable use of"). It is under a current scientism fallacy disguised under technocratic artifacts, from sophisticated social-ecological modeling to refined participatory Habermasian deliberation-consensus approaches, passing by institutional reform processes, and even power inequality struggles whereby technopoly stands as a development paradigm. Even when a change in production technology is not sufficient to achieve sustainability (Daly 1987), the scientism-technocratic fallacy makes us believe that technology is the solution to human-nature challenges regardless of the values behind it. In this transhumanist society, "technolatry" and consumerism go hand in hand (Ballesteros 2018).

Considering the current social and environmental situation of Lake Turgoyak, as well as the possible limitations of-the current technopoly paradigm in overcoming the current ecological challenges, it seems important to explore the human relationship with Lake Turgoyak from a values-based approach. This involves an understanding of the values underpinning this relationship and their evolution in terms of how they are transmitted and transformed and, so, the ultimate reason for these values. The societal concern driving the research is that this understanding may help to improve the ecological situation in Lake Turgoyak (figure 3).

\section{Methodology}

The research follows abductive reasoning and develops into a participatory case study that serves to build a geoethical dilemma. The dilemma exposes the values in how local dwellers relate to Lake Turgoyak and are later interpreted in light of the noosphere concept supported by field research of inhabitants' feelings, beliefs, values, and thoughts expressed by themselves in informal talks (Carson 2009). Abductive 


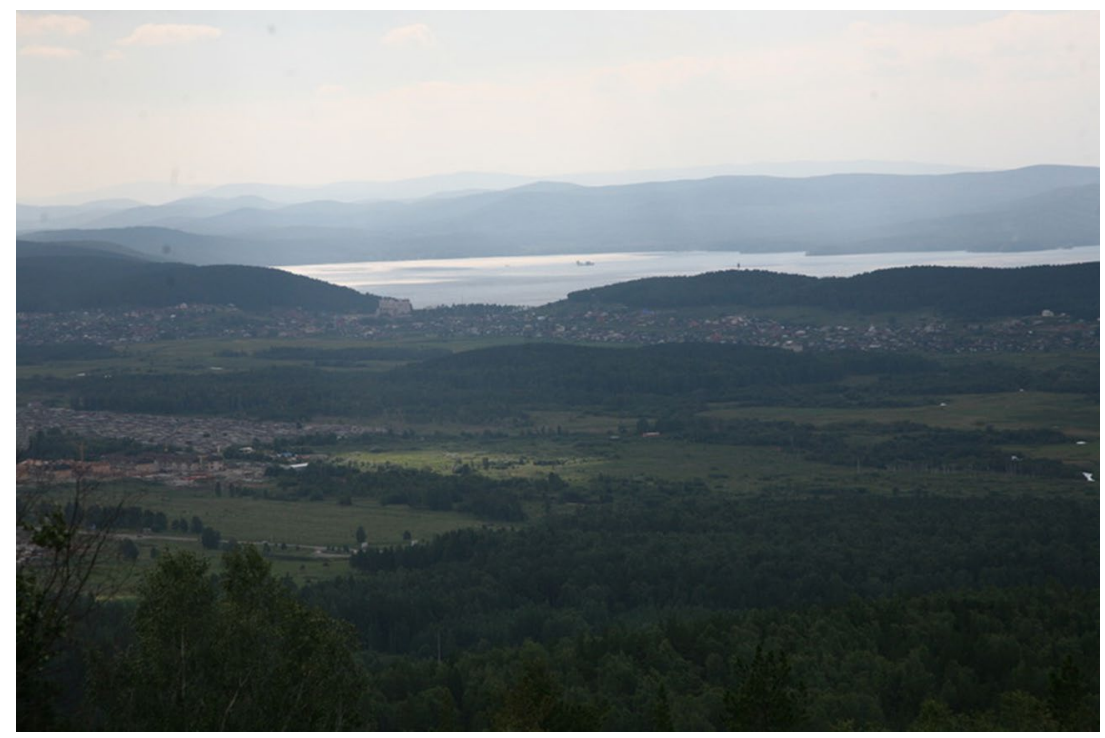

Figure 3. View of Lake Turgoyak from Miass (courtesy of A. Baygusheva 2016).

reasoning involves interpretative epistemologies that insist facts cannot be understood independently of how we observe and understand them (Carson 2009). In other words, rather than a deductive or inductive process, abductive reasoning tries to make sense of observations and lived experiences encapsulated in a geoethical dilemma, thus interpreting the reality in light of the noosphere concept.

\section{The Geosphere and the Noosphere}

Human-nature relationships have been explored considering evolutionary biology, social economics, evolutionary psychology, and environmentalism research fields (Seymour 2016). However, it is important to rethink this relationship in light of posthumanist discourses that consider the role of science and technology as a step toward overcoming the human species through genetic manipulation and artificial intelligence (Ballesteros 2018). The complexity of human-nature relationships shows that a man-made environment built on technocratic artifacts has a boomerang effect on social and environmental aspects that cannot be underestimated (Yanitsky 2018b). Although human intentionalism and pure mastery of the technique may coexist under a praxeology posi- 
tion (Prada-Rodríguez 2019), it seems appropriate to borrow the term socio-biotechnical systems (SBTS) (Yanitsky 2018b) to consider hybrid systems; where the role of human technocratic artifacts, or the way how humans relate to each other through technology and knowledge, institutionalized frameworks and struggling powers, are key in looking at the relationship with nature, not only in terms of interactions but also in a metabolic sense transforming biogeochemical cycles.

Considering the doubtless human connectedness to nature (Seymour 2016) and the idea that the world should be considered as a whole that comprises the totality of human relationships (Yanitsky 2018b), some cultural traditions assign sacred values to humans and nature (Ramis Pujol et al. 2015) in a such a way that environmentalism opens a person to the discovery of the spiritual sense of the human (Burgui 2011). This suggests SBTS, representing human and nature relations through technocratic artifacts, may be further explored considering their underlying spiritual values.

In the relationship between humans and nature, especially when referring to the management of georesources and their governance, the geosphere (the abiotic entity of nature) plays an important role. ${ }^{3}$ Finite material goods or conditionally renewable environmental services (Alfsen and Lorentsen 1987) sustain our current development patterns and man-made activities that benefit these georesources impact on biogeochemical cycles. In turn, these cycles alter geophysical processes affecting the most vulnerable populations (UNU 2007), making the human-geosphere relationship through technocratic artifacts a complex hybrid SBTS. Besides thinking in terms of water, soil, rocks, and minerals as georesources, the geosphere acknowledges the geodynamic processes in the interface between the lithosphere (the rocks and soils cycle), the hydrosphere (the water cycle), and the atmosphere (the air cycle) (Williams and Ferrigno 2012), as the substrate of the biosphere (Vernadsky 1945). The geosphere supports the living matter but also generates life in a social, cultural, and spiritual community sense, and the expression of its multiple manifestations in terms of rivers, lakes, and mountains may be considered as common beings (Bellaubi and Bustamante 2018). Geoethics consists of research and reflection on the values that underpin appropriate behaviors and practices, wherever human activities interact with the Earth system (Di Capua and Peppoloni 2019; Peppoloni and Di Capua 2015) and sets the moral basis in the relationship between humans and the geosphere.

The relational aspect between humans and the geosphere is introduced by Bellaubi and Bustamante (2018) using the concept 
of governability (Kooiman et al. 2008) regarding the qualities of the object of governance (the system-to-be-governed), its subject (the governing system), and the relationship between the two, applied to the human-geosphere relation. According to this definition, geosphere governability refers to the relation between humans and the geosphere through the technocratic artifacts and technocracies, meaning the governance and institutional models, the epistemological knowledge frames, and the environmental milieu (Rutherford 2017) reflected in the socio-dynamics of power asymmetries and struggles between humans. This understanding of the human-geosphere relationship is close to the interpretation of the Noosphere (Vernadsky 1945) made by Russian mathematician Nikita Moiseev (1989) as Earth system governance (Rindzevičiūtè 2018).

The Noosphere refers to the world transformed by the energy of human culture (Vernadsky 1938, 2012). It is produced and maintained by the increasing complexity of human interaction in socio-cultural, bio-physical environments (Wyndham 2000). The noosphere is often defined as 1) the biosphere transformed by human knowledge and action (human mind as the most powerful geological force [Vernadsky 1945]); 2) the spiritual embodiment of human thought into a unified whole (an evolving collective human consciousness [Teilhard de Chardin 1956]); and 3) a self-organized, self-regulating system on a planetary scale (see "autopoiesis," [Maturana and Varela 1984]), characterized by a structural and functional unity of natural and social subsystems. In this latter definition, its memory and regulator are thought of as unified social intelligence (Khairullina et al. 2019). However, "far from being contradictory guiding interpretations, the concept of Noosphere represents a unified interpretation of humanity's relationship with Nature" (Serafin 1987), aiming to "provide a comprehensive theory that explains the integration of culture and natural science as a global phenomenon" (Westbroek 1991, cited in Samson and Pitt 1999).

\section{The Geoethical Dilemma}

The geoethical dilemma is a geoprospective analysis method (Voiron 2012) to explore the human-geosphere relationship under a values-based approach (Bellaubi and Lagunov 2020). Geoethical dilemmas (Badera 2015; Burgui and Chuvieco 2017; Falck 2016; Gampel 2005; Marone and Peppoloni 2017; Nikitina 2014, 2016; Peppoloni et al. 2019) are not about "optimal" allocation of georesources management but, rather, exploring 
the values that underpin the human-geosphere relationship through technocratic artifacts. Under this view, the author defines geoethical dilemmas as the ethical attitude that results when different values in how humans relate to the geosphere, by relating to other humans, are put at stake. To look at the values of things means to consider our attitude in the human-geosphere relationship. Rationalization of instrumental-utilitarian and intrinsic-constitutive values may be represented by a range of attitudes depending on whether we consider the human-geosphere relationship in terms of georesources and environmental services or the geosphere as a common being. However, attitudes are confronted with social costs or gains that define technocratic alternatives and give credibility to our choice (e.g., different attitudes of conservation and preservation may result in a natural park or protected area as technocratic choices, depending on the social cost/ gains involved). ${ }^{4}$ In turn, credibility (Knott et al. 2008) fosters cultural change as a basis for "new" behavioral paths in our relationship with the Geosphere (Bellaubi and Lagunov 2020).

It is important to note that attitudes are the result of rationalization of values that may or may not mirror the stakeholders' values. ${ }^{5}$ The rationalization of values tries to give a sense of coherence to the human agency, as mentioned by Antonovsky (1987, cited in Golembiewski 2010) in terms of comprehension (apprehension of the environment), manageability (control on the environment), and meaningfulness (sense of self in the environment). Environment refers not only to the physical sense of the geosphere as a conceptual spatial representation but also to socially constructed relations in how humans relate to the geosphere manifestations through other humans as a cultural symbolic representational space. This embeddedness, highlighted by Lefebvre (1991) and Soja (2010) as a social production of space (Fuchs 2019), makes it evident that perceptions of the geosphere by sensations differ from those experienced, conceived, and influenced by a collective group or community.

Geoethical dilemmas are represented as a matrix where combined alternatives produce geoprospective scenarios (Houet and Gourmelon 2014) defined in terms of geosphere governability, meaning man-made impacts on the biogeochemistry cycles of the geosphere resulting in the alteration of geodynamic processes on vulnerable socioeconomic activities.

The geoethical dilemma of Lake Turgoyak builds on the development of a participatory case study conducted under a sociological intervention approach (Touraine 1980) that brings together quantitative 
and qualitative data from different sources, such as informal talks with local residents, oral histories, bibliographic review, and field observations, that is contemplation during nature walks. The data collection ceased once information became largely redundant (Dougherty 2019). The use of different sources allowed cross-referencing of information to enhance the coherence of the results (Bellaubi and Visscher 2016).

Informal talks were carried out between 2015 and 2019 with people from Turgoyak village and Mashgorodok. During this time, the author met with scientists, teachers, artists, writers, local residents, local authorities, representatives of citizens' associations, private sector entrepreneurs, small farmers, local hunters, people in public life, and local activists, henceforth referred to as interviewees (their names remain confidential). Interviewees had different ethnic origins (Russians, Bashkirs) and religious backgrounds (Muslims, Orthodox Christians, or atheists). The talks were developed in the form of storytelling, expressing personal opinions, perceptions, and self-attitudes about their personal relationship with the lake, political and management issues concerning the environmental management of the lake and, in some cases, shared traditional narratives and folklores around the lake.

Special consideration needs to be paid to the way these encounters took place. They were done during a normal daily routine with people without previous arrangements and sometimes took place more than once during different periods of the year. The talks started as trivial conversations to glean more detail regarding the environmental situation of Lake Turgoyak, to foresee possible solutions and the challenges in implementing them according to the interviewees' opinions. The ultimate question is to get into the why something needs to be done to improve the situation by considering the different values in how local dwellers relate to the lake (figure 4). The unfolding conversation follows the path of the Ignatian Pedagogy by seeing the problem scientifically, evaluating the ethical attitudes, reflecting on their meaning, and acting to attain effective ecological justice (Healing Earth 2021).

In addition to the informal talks, the author delivered several public speeches, one organized by the municipal library of Turgoyak village, one at the Mashgorodok Youth Centre, and one at an academic conference in South Ural State University, which served to expose and correct findings and to receive feedback by welcoming questions and answers from the public. ${ }^{6}$ In his role as foreign adviser to the Municipal Council of Miass and to the Ministry of Ecology of Chelyabinsk region, the author was in a privileged position to gain insight into the understanding of the situation on the political interests and priorities 


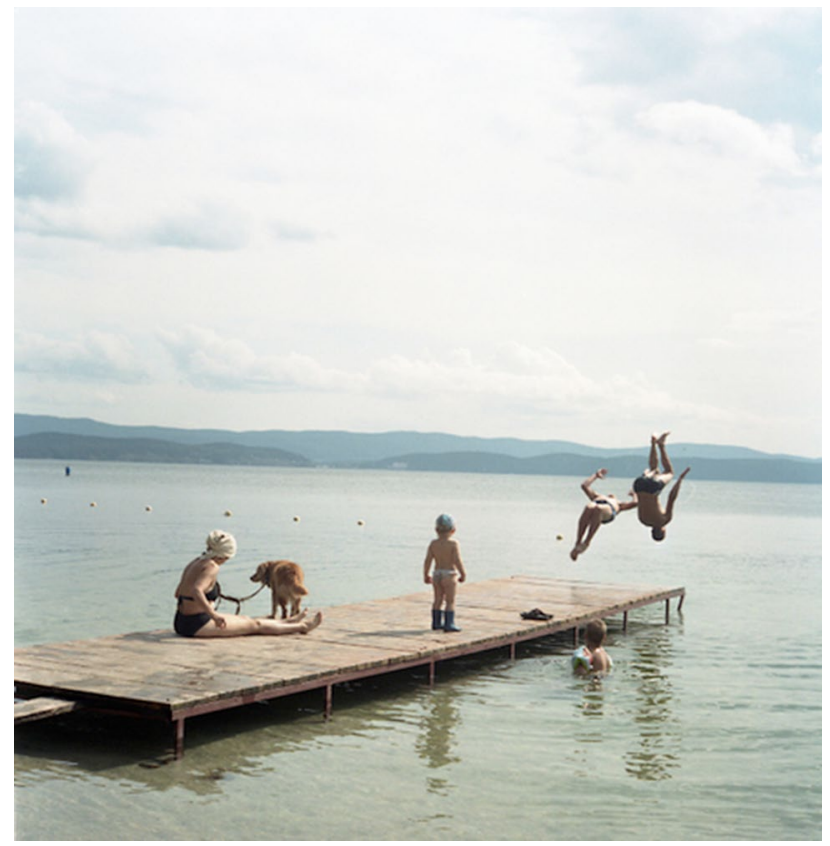

Figure 4. Locals bathing in Lake Turgoyak on a summer evening (courtesy of A. Baygusheva 2016).

of the local authorities regarding the ongoing environmental planning around Lake Turgoyak.

\section{The Case Study of Lake Turgoyak}

According to Lagunov (2004), Lake Turgoyak experienced four large ecologically historical periods (Lagunov 2004). The first period starts with the first dwellers on the shores of the lake around the Stone Age (although the exact chronology is a matter of discussion [Grigoriev and Vasina 2010]) to the mining colonies in the eighteenth century. ${ }^{7}$ During this long period, the lake was considered both sacred and forbidden by the original Bashkir inhabitants of the region; Vera (Faith) Island located on the east side of the lake hosts megalithic structures dating from the Stone Age (figure 5). During this period, relationships with the lake were based on folklore narratives. Thus, "The Island of Faiththe energetic heart of the valley and lake-served as the kingdom of the dead. Ancient people buried there their leaders and then the line 


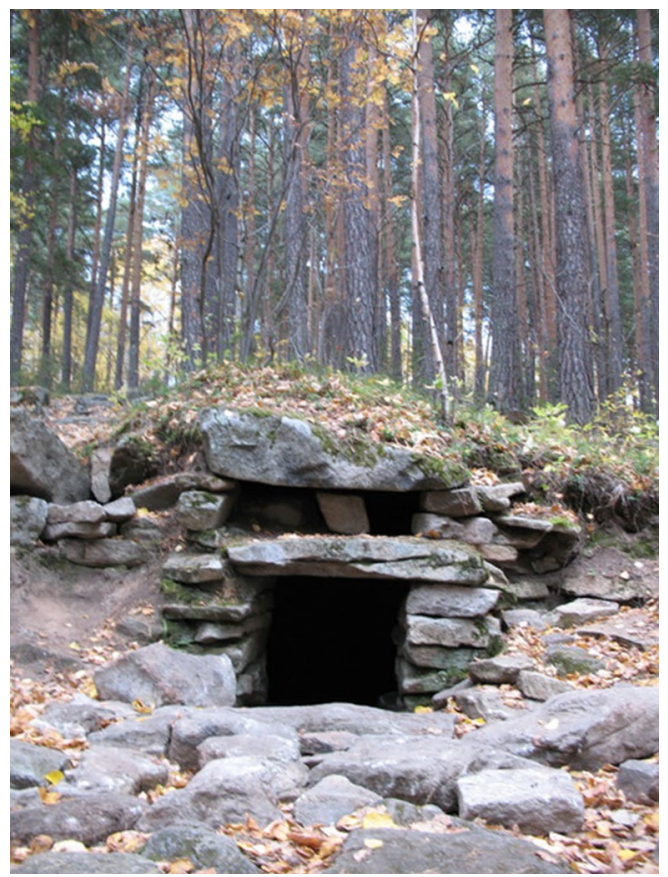

Figure 5. Vera Island Megalith in Lake Turgoyak dating from the Stone Age (courtesy of A. Baygusheva 2016).

between the world of the dead and the world of the living was visible and material" (Tsepaeva 2011:24). Environmental management could be characterized by a strong connection to nature and preservation of the place. During this time, almost no man-made impact existed on the lake, with the lake following natural spill cycles over the lower lands and draining into the Miass River.

During the second period, the region around Lake Turgoyak was colonized by Russian miners. The region, rich in minerals, such as gold, quickly turned into a flourishing mining center. The newcomers came into contact with Bashkirs, who had a deep spiritual awareness of nature, thus bringing different values into a confrontation. By 1831, the village of Turgoyak had ninety houses (Samoilova 2012, 2016), and during the nineteenth century Vera Island housed an Old Believers Orthodox monastery, which remains a place of pilgrimage to this day (figure 6). In this period, management involved the scientific and technological discovery of nature driven by the Russian Empire's ambitions to position itself between the Western powers. Impacts on the envi- 


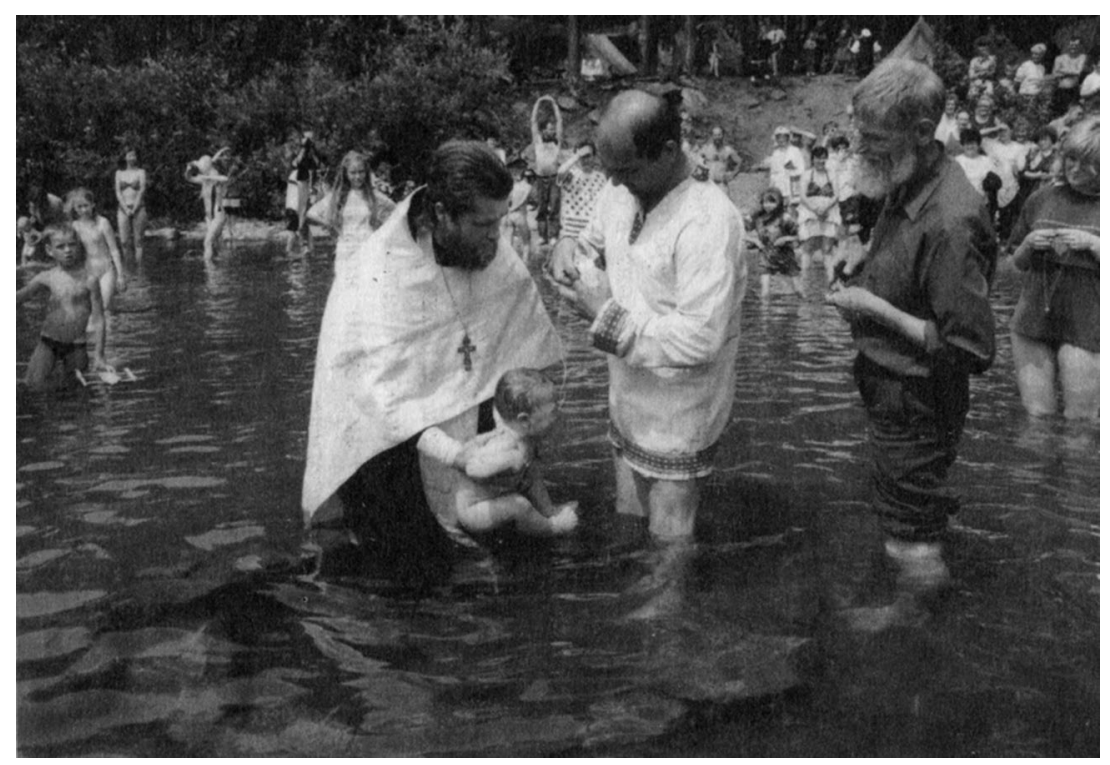

Figure 6. An Orthodox baptism by Old Believers on the shores of Lake Turgoyak. Source: Kornilova 2006.

ronment due to recreational activities have been documented since the beginning of the twentieth century (Sementovsky 1916).

The third period comprises the Soviet era, which was characterized by the mastery and control of nature as a form of management (Josephson et al. 2013). The state played a predominant role in controlling those activities where scientific and technocratic elites at the service of the state exploited natural resources for a higher ideological objective. During this time, Miass developed into a complex industrial center with the UralAZ car factory and the Makeyev Rocket Design Bureau in Mashgorodok. The 1960s witnessed an increasing environmental concern to protect some natural places within the region. Thus, on the recommendation of Chelyabinsk scientists, in 1961 Lake Turgoyak was declared a natural monument of regional significance (Lagunov 2008). This epoch is also marked by three big environmental nuclear catastrophes in the Chelyabinsk region: the direct discharge of liquid radioactive waste into the Techa River (1949-1956), the Kyshtym accident in 1957, and the transport of contaminated sediments from Lake Karachay in 1967. Fortunately, the accidents did not directly affect Lake Turgoyak. 
The fourth period covers modern Russia, infused by a nostalgic feeling of a patriotic historic-embedded renaissance (Laruelle 2017). Oligarch elites dominate and control the natural resources, as well as their production and distribution in the market. Economic development and economic benefits are prioritized over the protection of nature, which provokes environmental conflicts, such as the Eastern Siberia-Pacific Ocean oil pipeline. ${ }^{8}$ Nowadays, Lake Turgoyak suffers from considerable levels of anthropization, creating public health concerns (for example, during the summer of 2019, swimmers reported problems following a considerable increase in algae, and the news was reported in several local and regional newspapers). ${ }^{9}$ The environmental issues range from lack of environmental awareness among the visitors to deficient infrastructure, such as sewage and small wastewater treatment plants, solid waste collectors and waste recycling, or use of alternative clean energies for hotels and campsites. However, this situation is not new; a report on the status of the ecosystem of Lake Turgoyak in 1997 already highlighted the bad environmental state of the lake (Tkachev et al. 1997), pointing to the disruption of the water balance and the changes occurring to the lake's ecosystems due to a further increase in the content of biogenic substances and the increasing trophicity of the lake. Another environmental impact on the fauna and flora of Lake Turgoyak is related to Karabash's copper smelter located 80 kilometers from Miass. The waste material from Karabash is high in sulfide minerals, which creates atmospheric pollution (acid rain) that reaches Lake Turgoyak (Adey et al. 2011). The territory surrounding Karabash is assessed as an environmental disaster zone. Nevertheless, there are ongoing protection efforts, such as giving the lake the status of a specially protected natural area (Government of the Chelyabinsk Region 2007) and incorporating it as part of the Mountainous Urals Biosphere Reserve. ${ }^{10}$

The reasons for such a critical environmental situation relate to unclear laws, the lack of transparency on environmental decisions by public authorities as well as the lack of a strategic environmental and development vision. The latter is explained by the fact that the lake has different legal owners: the municipal authorities and the federal forestry agency, which makes it complicated to apply environmental norms and regulations. Indeed, as in many other regions in the Russian Federation, the main ecological problems relate to the delineation of powers, responsibilities and accountability scattered in different laws, and sometimes unreasonable assignment of powers on environmental issues (municipal governments are deprived of the power to exercise 
environmental control) (Kurlyandskaya and Golovanova 2012). As a result, the management of the lake is politically contested. The activists of the local environmental NGO "Save Turgoyak" constantly observe numerous environmental infringements, and they inform the local, regional, and even federal authorities, making those infringements public via social media channels. ${ }^{11}$

\section{Results: The Geoethical Dilemma of Lake Turgoyak}

The geoethical dilemma that surrounds Lake Turgoyak refers to its use for recreational activities that do not control and limit the anthropogenic load (see Bellaubi and Lagunov 2020). The lake is seen by many only as a recreational commodity under a utilitarian instrumental value. Even when environmental protection solutions could be implemented for sustainable recreational activities, many environmental and social questions arise regarding changing patterns in water quality recovery and soil pollution absorption, or erosion rates, as well as the degree of social acceptance regarding proposed measures. ${ }^{12}$ Such management options still tend to consider the lake as a georesource.

Considering the actual high tourism demand on the lake and the hydrological characteristic of the lake with no outlet for the water, technocratic solutions (green engineering) could involve very controversial social decisions. Furthermore, there exists distrust between local residents and authorities regarding their respective capacities to do something about the ecological problem, as well as there being possible hidden political agendas. Regulatory measures and economic sanctions and incentives, such as surveillance and control of visitors and entrance fees, remain challenging in a large open area and may require considerable investment with a burden on private entrepreneurs. Although nature-based solutions (Cohen-Shacham et al. 2019) may offer an array of possibilities, a values-based approach formulating a geoethical dilemma to explore cultural change may open new perspectives in seeking a new relationship between humans and the lake rather than immediate solutions.

The main stakeholders involved are visitors and tourists, local dwellers, the local NGO "Save Turgoyak" concerned about the environmental state of the lake, and the local authorities, together with the private tourist sector, who mainly look at the lake as an economic development opportunity. Tourists can be mainly divided into two groups: locals and visitors. The former make short visits to recreational camps 
(for a few days) or just camp around the lake for the weekend. The latter may not be familiar with the existing environmental problems, and they use the lake as a seasonal tourist destination. In practice, these two groups are considered the same in terms of the negative environmental impact on the lake. Local dwellers sympathize, to a greater or lesser degree, with the main environmental local NGO because they are seen by the locals as doing something about the existing environmental problems (for example, garbage collection campaigns). On the opposite side, local authorities look intently at the NGO as environmental activists confronting authority ${ }^{13}$. Finally, the private sector groups comprise a number of entrepreneurial activities of different businessmen with certain friendly relationships with the authorities who, in turn, see businessmen as actors of economic development in the region.

The geoethical dilemma is presented in the form of a matrix representing four possible scenarios in the human-Turgoyak Lake relationship in terms of associated environmental impacts on the lake (referred as I) and socioeconomic vulnerability on human activities (referred as V), and therefore geosphere governability. These scenarios result from combining attitudes based on utilitarian or intrinsic values that look at the lake in terms of a georesource or in terms of a common being, respectively, that in turn are not exempt from the social costs that result from the stakeholders' attitudes. The local NGO Save Turgoyak takes a clear stand to enforce environmental laws and hold politicians accountable, asking for more transparency to protect the lake. This confronts the local dwellers' accepting passivity through an attitude of dismay and feeling powerless toward the local authorities, which accept recreation and touristic practices. For local residents, adopting an attitude similar to the Save Turgoyak activists may bring associated social costs with unintended consequences; for example, tourists may stop visiting the "lake, perceiving local residents as troublemakers along with environmental activists and, eventually, a potential conflict between the inhabitants and the local authorities may arise. Interviewees also strongly expressed that "people know we need to do something [about the lake]," and meetings with different stakeholders indicate locals would prefer a "cleaner" Turgoyak. In its turn, the local authorities have a similar attitude toward instrumental values because accepting current recreational practices involves a quick economic rate of return, which is in line with business interests.

The matrix in table 1 depicts the four different possible scenarios in the geoethical dilemma of Lake Turgoyak that may vary according to different attitudes adopted by local dwellers and authorities in their 
Table 1. Impact and vulnerability matrix in the Human-Turgoyak geoethical dilemma

\begin{tabular}{|c|c|c|}
\hline $\begin{array}{c}\text { Recreational practices } \\
\text { involving local dwellers, } \\
\text { authorities and tourists }\end{array}$ & $\begin{array}{c}\text { The local dwellers accept } \\
\text { current recreational practices }\end{array}$ & $\begin{array}{c}\text { The local dwellers adopt } \\
\text { measures of environmental } \\
\text { protection }\end{array}$ \\
\hline $\begin{array}{c}\text { Local authorities accept } \\
\text { the current recreation } \\
\text { activities }\end{array}$ & $\begin{array}{c}\text { Alternative 1 } \\
\text { I: deterioration of ecosystem } \\
\text { and water quality }\end{array}$ & $\begin{array}{c}\text { Alternative } 2 \\
\text { I: certain protection/initiatives } \\
\text { measures in place } \\
\text { of the loss of the touristic } \\
\text { attraction }\end{array}$ \\
$\begin{array}{c}\text { L: open confrontation with } \\
\text { local authorities }\end{array}$ \\
$\begin{array}{c}\text { Alternative 3 } \\
\text { environmental protection } \\
\text { laws and regulations }\end{array}$ & $\begin{array}{c}\text { I: some recreational areas may } \\
\text { not be in compliance with law } \\
\text { V: improvement of social and } \\
\text { political image of the region }\end{array}$ & $\begin{array}{c}\text { V: considerable investment } \\
\text { efforts }\end{array}$ \\
\hline
\end{tabular}

relationship with the lake. Scenario one represents the current situation in the human-Turgoyak relationship. This scenario may potentially lead to a socioenvironmental tragedy. Scenario four represents the best geosphere governability outcome in the relationship between the local dwellers, the authorities, and the lake, although it may involve considerable private and public investment to restore the natural environment of the lake as well implementation of protection measures. Although the environmental and socioeconomic benefits of scenario four are obvious for all stakeholders, the current stakeholders are looking at the lake as a georesource lead to scenario one with a negative environmental impact on the lake and high socioeconomic vulnerability.

In order to reach the outcomes of scenario four, the local authorities and local dwellers need to consider the intrinsic values of the lake. This means enacting a solidarity principle (Tischner 2005) under which local authorities and residents expect the other's attitude does not reflect self-interest in adopting instrumental consumerism values with regard to the lake. Instead, they seek a common goal according to shared values for a better socioenvironmental outcome in the human-geosphere relationship. Solidarity is possible when the common values are shared by a community by engaging in an ecumenic dialogue, a dialogic dialogue of values (Küng 1991; Melloni 2012; Panikkar 1999), increasing credibility scenarios, and creating cultural change (Knott et al. 2008;). Cultural change is based on cultural capital (Bourdieu and Passeron 1978), 
developing a geoethic-forward attitude toward transforming the values in how humans relate to the geosphere (Bellaubi 2020; McIntosh and Carmichael 2016). Solidarity as cultural capital means going beyond cooperation in sharing benefits on georesources. Solidarity focuses on recognizing the lake as a common being and means that humans' attitudes would reflect the intrinsic values of the lake, not as a resource to profit from (e.g., a popular tourist destination) but as a manifestation of the geosphere to take care of.

The dialogue around Lake Turgoyak may unfold in a participatory and reciprocal process, meaning the more the local authorities show openness to listen and accept others' points of view, the more residents can influence change, and so the authorities are perceived as transparent and "good" rulers. At the same time, the dialogue runs as a pedagogic process helping to put forward the right questions, searching for common values between authorities and local dwellers in order to build new relationships between humans, creating a community-or, in other words, a communion with others and ultimately a communion "with" Lake Turgoyak (geosphere), going beyond the concept of empowerment. ${ }^{14}$ The ecumenic-ecologic dialogue is not about what kind of tourism Turgoyak should follow and how to achieve it, but rather a full politically contested process of companioning and counseling the different human actors interacting with the lake (Étienne 2010).

The different interviewees expressed their environmental concerns about the lake, as well as their willingness to engage in a broad ecumenic-ecologic dialogue, breaking the inertia on their own attitudes. This is especially important in a moment when the current local authorities are thinking about the possibility of declaring Lake Turgoyak a national park (Lagunov 2019). Considering the challenges faced in the past by the national parks in Russia (Newell and Henry 2017), a long-term risk exists that a top-down approach taking a specific "technocratic artifact" solution may not bring the expected results in terms of environmental preservation. Instead, showing the geoethical dilemma as a pedagogic process has the considerable advantage of being a conscious and self-liberating exercise of critical thinking to reflect together on common challenges. 


\section{Discussion: Exploring the Spiritual Dimension of the Noosphere in Lake Turgoyak}

This section examine in detail the apparent contradiction between attitudes and values expressed by some interviewees. These contradictions could be due to the fact that an attitude results from value rationalization but does not necessarily mirror the meaning or value that Lake Turgoyak holds for the local residents. Further to this, the section elaborates how these values are transformed into an ideology of resistance, shaping their popular ecological response. The interpretation of this reality is then derived from the concept of the Noosphere.

\section{Revisiting the Concept of the Noosphere}

Revisiting and enlarging the noopshere concept allows the structuring of a coherent theory to interpret the identity values within the geoethical dilemma of Lake Turgoyak in order to understand mismatches between values and attitudes. The concept of the noosphere has catalyzed multiple debates between scholars on its interpretation (e.g., Bischof 2007; Bohle and Preiser 2019; Galleni and Scalfari 2005; Khairullina et al. 2019; Korobova and Romanov 2014; Levit 2000; Moiseev 1989; Nordblad 2014; Oldfield and Shaw 2013; Rindzevičiūtè 2018; Samson and Pitt 1999; Serafin 1987; Sikorskaya et al. 2016; Torretta 2015; Wyndham 2000). At its origin, the concept of the noosphere results from the collaboration of several scholars in the middle of the twentieth century: the Russian geochemist V. I. Vernadsky, the French Jesuit paleontologist P. Teilhard de Chardin, and his friend the natural philosopher Le Roy, and it may be a common understanding that the coevolutionary concept of the noosphere relates to how the evolution of the human mind disrupts the biogeochemical cycles of the geosphere that allow the sustainability of the biosphere. It appears the concept of the noosphere has two dimensions: as a material component of living and nonliving matter (Vernadsky 1945) and human eschatological evolution (Teilhard de Chardin 1956). The material dimension of the noosphere refers to human physical objects and processes in their interaction with the geosphere (Bohle and Presier 2019) and, thus, to geosphere governability; however, Vernadsky acknowledged that the sphere of the human mind develops with the emergence of human self-awareness. This human consciousness of being rooted in a collective unconsciousness of belonging to the Whole as though by S. L. Frank (Bischof 2007) and 
C. J. Jung (1969) (Mcintsoh and Carmichael 2015), is at the base of the human relationship with the geosphere through technocratic artifacts that alter the biogeochemical carbon cycle.

The spiritual dimension of the noosphere, or the values that sustain technocratic artifacts and their technocracies, is helpful in the understanding of the values that underpin the relation between the human and the geosphere through technocratic artifacts and their technocracies. To elaborate this spiritual dimension of the noosphere, the author follows the interpretation of Margenot (2009) about the works of the Spanish philosopher M. de Unamuno (1902) and also the Spanish poet A. Machado (1912). ${ }^{15}$ According to Unamuno, the concept of intra-story is the story of the silenced majority of humans who underlie history. In its turn, the concept of intra-time of Machado states that the main essence is the eternal union with the land. Both terms put together to allow the argument that the human, through collective unconsciousness, identifies himself within a specific territory that carries the memories of the ancestors, that is the memory of the geosphere, as the path of human coevolution in relationship with the geosphere. Here, the idea of the union with the territory must be read from a cultural geography perspective (Lorenzo 2006; Rodriguez 2006). The territory is not only seen as a socio-political construct or a space of power but also that the land that has power in itself (Berry and Nichols 2019) and is a holder of values and memories that frames an identity.

The intra-story and intra-time concepts developed by Unamuno and Machado link ancestors' remembrance with a specific "geospheric" place, a historic ecological memory where the man is intuitively self-perceived looking for his essence; the land becomes the symbolic embodiment of the human soul. Spiritual meaning values bounded on history are transmitted through identity through a coevolutionary process during geological time. Following this argument, the union with the land is formed through our ancestors and projected to the future through the coming generations. The human mind developed self-awareness of the collective unconsciousness through the narratives of past human relations with the geosphere in the present and projected toward the future, which would otherwise be forgotten. Likewise, the geosphere holds the "living memory" of our ancestors who, in turn, modified the biogeochemical cycles: a geological historical memory. The carbon cycle becomes not only a biogeochemical process but carries the spiritual transmission of meaning that holds the memory of our ancestors through their relationship with the geosphere; a coevolution of instrumental and intrinsically embedded inherited values (Groenfeldt 
2016) that define the identity of communities in history. The recognition of the spiritual dimension of identity is a form of rendering tribute to our ancestors and letting their voices be heard for present and future generations, bringing their memories to life (Milosevich-Juaristi 2018). Their voices are the voices of the land they once inhabited and were in communion with. Expressions of cultural identity and folklore may be referred to as "rituals and liturgies" and the human relationship with the geosphere becomes a mystic exercise of evoking and awakening spiritual feelings connecting our soul to our ancestors through the land, an "icon" that carries our collective memories.

Interpreting cultural identity expressions as a spiritual act, our souls become interconnected with our ancestors' souls through the memories of the places they lived. This mystic experience constitutes the spiritual knowledge (gnostic knowledge) of the sacred, the whole (McIntosh and Carmichael 2016). The land, where the voices of ancestors lie, is not a sacred entity per se but a manifestation of the sacred as a hierophany (Eliade 1959), which puts us in contact with the sacred, with the divine, with the creator, a creation force, an eternal logos, the sense of self that transcends or whatever one's interpretation of this is (Promotio Iustitiae 2011).

\section{Identity Is Connected Spiritually to the Geosphere through Our Ancestors}

What does it mean to be Russian, and how do Russians perceive themselves in relation to Russia? So what is Russia? These big identity questions, beyond the scope of this paper, make the point, however, that identities and ideologies are connected. Quoting Franklin and Widdis, "Identity is not a 'thing' to be objectively described. It is a field of cultural discourse. It is each person's self-perception: as an individual, in relation to a group or groups, and by contrast with other individuals and groups" (2004, xi), and this self-perception is also about the self-identification with their Land. Thus, this perception is expressed by a common ideology that represents common relational values in relation to the land.

Russian society has a self-perception of a renewed strong "national" identity (Tishkov 2008), although this perception can largely change from rural to urban areas, from east to west, and between social classes. While formulating the geoethical dilemma of Lake Turgoyak and during the informal meetings, people expressed a strong sense of 
Russian self-consciousness identity as, somehow, a kind of nostalgia inherited from the Soviet times that is stronger within the generation aged thirty and older (meaning those who received a Soviet education). Historically, the region around Lake Turgoyak has been an active mining center since the eighteenth century that has left a profound sense of identity, heritage, and tradition (Adey et al. 2011). In Miass (approximately ten kilometers from Lake Turgoyak), this sense of identity is expressed as pride by the fact that the city itself was an industrial complex for car and truck manufacturing during World War II, and this industry was vital in defending Russia from its enemies. During Soviet times, Mashgorodok, the root of which means machine (mashina), was a scientific research city (a ghost-city named SKB-385) developing missile technology for the Russian Navy. Proof of the pride in the Mashgorodok identity is the event that commemorated the sixtieth anniversary of the neighborhood during the summer of 2019, which included poems and song performances about "My Mashgorodok" (Moi Mashgorodok) and neighbors' gatherings around parks and public areas (figure 7). ${ }^{16}$

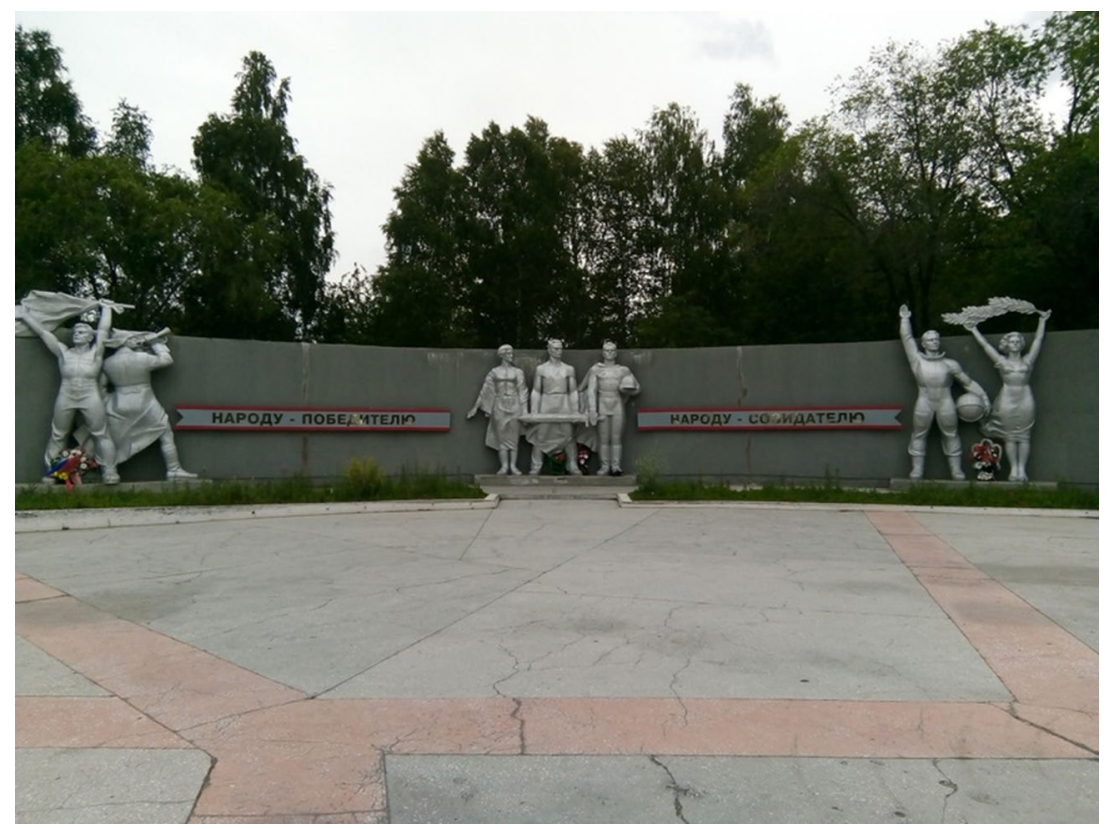

Figure 7. A commemoration monument in Mashgorodok (the inscription in Russian reads: "to the victorious nation ... to the creator nation") 
This "spiritual" self-consciousness experience of "being" is expressed as "belonging to" and thus "having an identity," and was mentioned in different talks with the inhabitants of Mashgorodok and Turgoyak village: "you [are] us" (ty nas), when referring to foreigners as "them" being "accepted" amongst "us." ${ }^{17}$ The "us" does not solely refer to the person but to the person as being part of the land, by developing a Russian soul (dusha), an emotion that unites "in spirit," staying "in communion" with the Motherland (a timelessness feeling of belonging with the Motherland) (Berdyaev 1918). Thus, the Russian Land or Motherland constitutes an identity symbol that unites Russians in the past, in the present, and in the future. Another expression from the interviews with the locals that summarizes this spiritual feeling of union between them and the lake as a mystic experience (Taylor 2009) shows a connection between the soul of the lake (as an entity that gives life and, thus, is alive and has a soul) and the soul of the person: "the [soul of the] lake asks (dusha prosit)." These ideas are rooted in the logoi or purpose of things of the Orthodox tradition (Chryssavgis and Foltz 2013; Obolevitch and Rójek 2014) that participate in an eternal logos and enables the mystic experience in how the locals "communicate" with the lake through a kind of liturgy when they walk around in contemplation.

\section{Framing an "Ideology of Hope" around Lake Turgoyak}

The described self and common perception of identity is the specific geospheric expression of the Russian dusha, a mystic experience of the communion with the Russian Motherland through ancestors and projected to the future generations. This identity is self and collectively perceived as a hope, as expressed by one interviewee when talking about the lake in the past "before there was hope in the future." This emotional feeling, an almost eschatological ideal that differs from utopia (Moltmann 1967), frames an ideology: a spiritual resistance ideology of "being in hope" in the present as a mystical exercise. This spiritual resistance is expressed by another interviewee: "in summer we do not go to the lake" and complemented by another: "we go [to the lake] later at night when nobody is around." However, the lake remains in the people's thoughts. These feelings go beyond the intention of avoiding crowded places or avoid putting more environmental pressure on the lake; they portray an attitude of reverence toward the lake. This attitude shows the locals' restraint in enjoying the spiritual contact with the lake; they resist the temptation of "saturating" a lake 
already full of tourists in the summer, waiting until the lake is quiet to contemplate it as a symbol of hierophany.

The spiritual eco-resistance ideology in hope could be portrayed as a pastoral attitude, both spiritual and pedagogic, that resembles the kitchen talks during the Soviet time (or the dissident kitchens). In the Soviet era, the "kitchen talks" (kukhonnyii razgovor) were times of debate inside the "Khrushchyovki,y" small apartments built during the 1960s at the time when Khrushchev was directing the Soviet Union. The apartments served to quickly accommodate the growing working class in the big cities and industrial areas. In the apartment kitchens, families and friends used to meet and hotly debate political and economic issues and reflect on them. They were an "open" space of freedom and critical thinking where people could not do anything to change the political situation but somehow remain loyal to their souls, at the same time spreading these meaning values all around their relatives, colleagues and friends and making the feeling of community and identity even stronger. ${ }^{18}$ Nowadays, these kitchen talks keep on going in families' and friends' gatherings on the topic of the environmental situation of Lake Turgoyak to discuss what can be done and how to improve the situation of the lake. In Mashgorodok and Turgoyak village, relatives and acquaintances deeply debate the environmental deterioration of the lake and how the lake had changed, looking at the past and remembering the old times when the lake was untouched and clean, and fishing was abundant. People also reflect on the future of the lake, about possible solutions, and the skepticism of the local administration handling the problem of doing something about it. These spaces of debate constitute the ongoing construction of a renewed identity of being in communion with the lake, from the ancestors' remembrance to the hope in the future of preserving the lake as a place of social and spiritual gathering for future generations. It is in this way the local dwellers of Turgoyak face their dilemma, resisting in hope within their spiritual identity values while taking an apparent attitude of resignation. This view of resistance resembles that of the two Jesuit priests in seventeenth-century Japan in Martin Scorsese's 2016 movie Silence (Montevecchio 2017), holding their faith but dropping their beliefs (Panikkar, 1999), or to take a more realistic stand, the spiritual resistance during the Holocaust in the Jewish ghettos. ${ }^{19}$

In these local debates, it is interesting to observe how those who do not ascribe to this ideology could be perceived as betraying their own ancestors and future generations. Using terms of Russian nature folklore, while "betrayers" of the Motherland may dominate and stay in 
power or be influential elites venerating the technopoly idol, the silent majority would resist, devoted to Turgoyak in a spiritual self-practice looking for credible epic heroes (bogatyrs). As the Siberian activist Irina Platonova puts it in an interview with the socio-environmental scientist O. Yanitsky: "people without forests are people who have been cheated and robbed. A forest isn't just the trees outside your window. Nature means a forest with animals and insects. You know here I often look at the sky, because here in the city it's the only thing that links me to nature. Another thing is that a person who is deprived of nature is also deprived of literature, and of the ability to understand it. Such a person can't be a patriot, because all of Russian ... art, painting, literature and music are linked with nature." ${ }^{20}$

The symbiosis of identity-ideology brings us back to the concept of intra-history and intra-time; the identity framed on our ancestors and that extends toward the future generations through an evolutionary process looking for the eternal union between human and Land unfolding in an eco-ideology. Using an analogy with the Tarkovsky films (Robinson 2006), ideologies are timeless (mystic moments), transcending acts of spiritual cognition with values through which we understand the world. Identity is the search of the soul, whereas ideologies act as the machine of the soul transforming the identity values that are finally transfigured into technocratic artifacts. Ideology is understood as an imaginary of spiritual ideas that unfold in an array of values through narratives, beliefs, and myths, making others adhere to what the ideology claims (Žižek 1989). The ideology transports us and transmits powerful "presence" feelings connecting us with the past through the present, bringing hope to the future (in a similar way to the notion of "presencing" of Heidegger). Ideologies are identity-based as an intra-historic process in a place and in an intra-time: the land. The land holds a power, an identity power, where the inhabitants are part of the place, and the place frames the people in a continuous creation of space (Lefebvre 1991). One can trace identities on the map as expansion or retreat of ideologies that sustain empires, states, and nations. (Franklin and Widdis 2004). It thus seems to be logical that ideologies can be framed under identity processes where a change in values will involve a rethinking of the identity as a self-perception with regard to the other individuals, meaning reinterpreting historical facts from a hermeneutic perspective, with the certain risk of rewriting history.

At the same time, the ideology represents — as intra-time based-the continuous evolution of the memory by the human self-consciousness process that is transformed into the collective unconsciousness when 
looking for his essence. There is a continuous transformation of the Motherland into an ideology. The identity values are transmitted and transformed in time, through generations but, in essence, remain the same. In other words, the big steppes and the big forests are reinterpreted during different periods (Kievan, Tsardom, Imperial, Soviet, and post-Soviet), but russkaia zemlia (the Russian land), the symbolic unbounded landscape, persists in essence (Franklin and Widdis 2004) and becomes rodina. ${ }^{21}$ Thus, the identity is historically bounded (the intra-history) in the ancestors but also projected toward the future generations through the present generations by our self-conscious evolution toward the collective unconsciousness (the intra-time), the search of the essence, the eternal boundedness to a place.

\section{Conclusions}

In the last decades the ecological situation of Lake Turgoyak and the surrounding land is unsustainable due to the chaotic tourism development. Environmental activists from the local NGO constantly observe a lot of infringements and inform the local, regional, and federal authorities, even publicizing these social media but, generally, it makes no difference. This current grassroots environmental activism of the population emerges as local protest actions against activities that produce harm to nature and people around them (Yanitsky 2018a); it is inserted in the ongoing ecological debate in Russia as a type of social protest against the insufficient activity of the government in solving socio-environmental problems (Haliy 2001).

In parallel with a struggle that confronts the powers that be (McIntosh and Carmichael 2016), runs an untold and silent story; the history of Mashgorodok and the village of Turgoyak attached to Lake Turgoyak. Further than respect toward nature as a moral duty or an environmental ethic, local dwellers around the lake express strong, spiritual ecological values that closely relate to the feeling of identity; an identity that is acquired not by birth or descent but by a spiritual connection of belonging to the place, a community in communion with the land. Values are held in the memory of the land, transmitted throughout generations, and transformed into expressions of resistance in hope for a better future expressing an eco-ideology. "Ecological resistance is an evolutionary expression of self-defense, a necessary adaption for re-harmonizing the Human and non-Human words" (Taylor 1995). At Lake Turgoyak, locals contemplate and walk around the lake, paint 
the beautiful landscape, or write poems about the old times in a way their souls become closer to the soul of the lake. These attitudes are manifested in moments of peace and inner calm, moments of reverence for something that transcends. Thus, resistance is expressed through a spiritual ecological and mystical dimension that recognizes our relationship with the geosphere is connected to other humans, becoming a community in communion with the whole and hope constitutes a powerful spiritual internal force to resist, a hope that is a living, loving force (Moltmann 1967).

This spiritual resistance as ecological mysticism is framed in the form of identity values transformed into an eco-ideology that constitutes the answer of many local residents to the dilemma they are facing: a tragic ecological scenario versus a possible future in hope. It is in the identity values that hope is sustained to achieve a point of social and environmental justice, harmonizing the humans' relationship in communion with the lake, and it is from this stance that a debate on technocratic solutions should take place. An interesting question is if both popular responses, that of the local NGO and one of local dwellers, can come together in the form of spiritual activism. "Spiritual activism means the spiritual underpinning of action for social and environmental justice. It is an underpinning because it is not sufficient to think of spirituality—that which gives life-as an optional "dimension" or "element." If activism is not grounded in spirituality, it cannot be sustained in the long run: we either burn out or sell out as the oil of life runs low"22).

The underlying identity values in the relation between humans and the geosphere in Lake Turgoyak, as exposed in the geoethical dilemma, are interpreted using the noosphere concept. The latter has embedded both a material and a spiritual dimension: the technocratic artifacts and their technocracies sustained by the values underpinning the humangeosphere relationship. The material dimension can be expressed as geosphere governability in terms of human impacts by the disruption of the biogeochemical cycles and the resulting alteration of the geodynamic process affecting the vulnerability of human activities.

The spiritual dimension of the noosphere merges the intrinsic and instrumental values that sustain technocratic artifacts into identity values that give a "meaning" to the people and the land they inhabit. This view highlights the existence of systemic ecological values (Rolston 1988) that overcome the classic instrumental / intrinsic dichotomous position, giving a sense of spiritual meaning to the humans' relationship with the geosphere (James 2019). This spiritual dimension defines 
the existential sense of self, the identity of being a "part of" in relationship with the whole or the ultimate why; a relation that is a gnostic way of knowing. Identity refers to the meaning of how humans relate to the geosphere and, ultimately, our communion with the land that holds the memory of our ancestors. These identity values are transformed into ideologies that, in turn, transfigure into technological artifacts on how humans relate to the geosphere.

By looking at the relations between identities, ideologies, and technocratic artifacts, the concept of the noosphere becomes an alternative knowledge paradigm based on spiritual experiences and perceptions of the reality, reconciling humans with humans and through the geosphere with the Whole (Promotio Iustitiae 2011). The noosphere paradigm contests the one of technopoly, representing the Anthropocene (Bellaubi 2020) that relies on rational knowledge and technocratic efficiency concepts and is based on a "technical morality" (Ellul 1980). In doing that, the noosphere acquires cultural and ethical importance in terms of ecological justice (Jesuit Social Services 2018) and spatial justice (Lefebvre 1991; Soja 2010) because it relates social with environmental issues exposing the importance of other humans as a basis for our relationship with the geosphere. In the epoch of ecological wars (Yanitsky 2020), we need the active transformation of societal structure but also the development of "a new morality." Evolving toward the noosphere requires the radical restructuring of our entire being; the shift of standards and ideals, "where the main condition for the transition to the Noosphere is the deep transformation of the economic, technocratic human into the ecological, noospheric human, changing the vector of civilization's development from the material into the spiritual" (Khairullina et al. 2019: 716).

Going back to Lake Turgoyak, it remains to be seen how to articulate an ideology of resistance in hope, with the daily lives of the people, to create real cultural change in their relationship with the geosphere. I suggest a couple of ideas. First, it is necessary to undertake "the long march through the institutions" (Dutschke 1980), not only to silently and intellectually foster the change of structures of power from inside but also as a self-individual transformation process and critical self-consciousness as a form of spiritual activism. Second, but not last, it is imperative to engage in a geoethics dialogue that ranges from responsible anthropocentrism and ecocentrism views passing by eco-humanist and theocentric positions, whatever the cultural and religious traditions and backgrounds, because how long we can inhabit the same Earth without sharing different realities and values? 


\title{
Acknowledgments
}

I would like to dedicate this paper to the people of Mashgorodok. I thank Mrs. Svetlana Podkidysheva for translating the Russian interviews into English.

\begin{abstract}
Francesc Bellaubi is an international consultant with more than twenty-two years providing technical assistance to development organizations, international agencies, NGOs, and research institutions in different countries of the Americas, Africa, and Asia-Pacific on natural resources governance and management. His research has focused on geoethics and geoprospectives at the South Ural State University, Russia;exploring how individuals relate to each other and with nature and the role of pedagogy and leadership in spiritual activism. He is a member of Silene, a nonprofit association based in Catalonia that focuses on the study, dissemination, and promotion of the spiritual and intangible cultural heritage values inherent in nature.
\end{abstract}

\section{Notes}

1. "Ecological rating of the regions of the Russian Federation," Green Patrol, n.d., http://greenpatrol.ru/sites/default/files/styles/1._reyting_leto_2018.pdf.

2. "Do Schools Kill Creativity" Robinson, K. n.d., http://sirkenrobinson .com/.

3. Vernadsky (1998 [1926]) divided the Earth into envelopes, or geospheres, identifying the upper geosphere with the biosphere, "named Nature by Humboldt or Gaia by Lovelock" (Grinevald 1998). According to Vernadsky, the biosphere connects living organisms, the cosmic energy flow, and the cycling of chemical elements.

4. "Conservation versus Preservation?," https://www.usda.gov/media/ blog/2016/03/22/conservation-versus-preservation.

5. Bellaubi and Visscher (2016) point out the difficulties in asserting stakeholders' values when working on governance integrity, but only to point out "risky" unethical attitudes. In the same way, attitudes reflect a positioning regarding values but do not necessarily express the value held by the stakeholder.

6. "Geoethics," https://it-cube.ddt-miass.ru/новости/; “Ecoengineering 2.0," https://it-cube.ddt-miass.ru/; “The right question on Lake Turgoyak," http://www.glagolmiass.ru/articles/society/pravilno_zadannyy_vopros/.

7. "Secrets of the Vera Island in Lake Turgoyak," n.d., http://earth-chronicles .com/histori/secrets-of-the-vera-island-in-lake-turgoyak.html. 
8. “The Eastern Siberia-Pacific Ocean oil pipeline," n.d., https://ejatlas.org/ conflict/the-pipeline-eastern-siberia-pacific-ocean.

9. Miass people who bathed in Turgoyak are covered in strange spots," n.d., https://miasskiy.ru/20190720-miasczy-iskupavshiesya-v-turgoyake-vnovnachali-pokryvatsya-strannymi-pyatnami.

10. "Mountainous Urals Biosphere Reserve, Russian Federation" April 2019. https://en.unesco.org/biosphere-reserves/russia/mountainous-urals.

11. https://vk.com/saveturgoyak.

12. In this case, to facilitate the comprehension of the dilemma, the term protection includes conservation and preservation to express the recognition of Lake Turgoyak as a common being.

13. Environmental activism associated to the Rise of "Civic Society" in Russia was in the past a platform to bring forward the critics to the Soviet regime (Newell and Henry 2017) and still today agglutinates people of different political views but with a critic voice against the government.

14. Communion can be understood as ecumenic participation to build a community.

15. This interpretation is closely related to the idea of sobornost developed by Slavophile Russian philosophers between the nineteenth and twentieth centuries and described in Bischof (2007).

16. “My Mashgorodok,” n.d., http://miasslib.ru/2019/07/02/.

17. This expression does not have a verb. There is an immediate identification of the individual with the community and with the Motherland.

18. Source: "Dissident kitchens," n.d., http://www.kitchensisters.org/ hidden-kitchens/dissident-kitchens/.

19. In Holocaust terminology, "spiritual resistance" refers to attempts by individuals to maintain their humanity and core values despite Nazi dehumanization and degradation. Such unarmed resistance came in many forms, religious and non-religious, cultural, and educational. "Spiritual Resistance During the Holocaust," n.d., https://www.yadvashem.org/articles/general/ spiritual-resistance-during-the-holocaust.html.

20. "Russian environmentalism: Conditions and prospects," n.d., http:// gadfly.igc.org/russia/rus-envt.htm\#N_18_.

21. There is a distinction between russkaia zemlia as a geographic place, the land of the Russians, and rodina or the birth place, the Russian Motherlands, but that become a single idea by identity-ideology symbiosis.

22. "Spiritual Activism: Leadership as Service" n.d. http://alastairmcintosh .com/spiritualactivism/ 


\section{References}

Adey, E. A., R. K. Shail, F. Wall, M. Z. Varul, P. H. Whitbread-Abrutat, C. Baciu, T. Ejdemo, I. B. Lovric, and V. Udachin. 2011. "Corporate social responsibility within the mining industry: case studies from across Europe and Russia." In Proceedings of the Aachen International Mining Symposia (AIMS): 5th International Conference-Sustainable Development in the Minerals Industry (SDIMI 2011), Aachen, Germany, June 14-17, 2011, 153-170.

Alfsen, K. H., and L. Lorentsen. 1987. Natural resource accounting and analysis: The Norwegian experience 1978-1986. Oslo: Central Bureau of Statistics.

Antonovsky, A. 1987. Unravelling the mystery of health. San Francisco, CA: Jossey-Bass.

Badera, J. 2015. "Problems of the social non-acceptance of mining projects with particular emphasis on the European Union-a literature review." Environmental \& Socio-Economic Studies 2 (1): 27-34.

Ballesteros, J. 2018. "La nueva gnosis como negación de las diferencias ontológicas y de las deficiencias inevitables." In Secolarizzazione e diritto. Studi in onore del Profesor Francesco D' Agostino, ed. S. Amato, A. C. Amato Mangiameli and L. Palazzani, 207-216. Turín: Giappichelli.

Bellaubi, F. 2020. "Una ética de la tierra para un mundo constantemente cambiante." [An Earth Ethic for a Constantly Changing World] Razon y Fe 281, no. 1445: 331-344.

Bellaubi, F., and R. Bustamante. 2018. "Towards a new paradigm in water management: Cochabamba's water agenda from an ethical approach." Geosciences 8 (5): 177.

Bellaubi, F., and A. Lagunov. 2020. "A value-based approach in managing the human-geosphere relationship. The case of Lake Turgoyak (Southern Urals, Russia)." Human Ecology 48: 599-608.

Bellaubi, F., and J. T. Visscher. 2016. "Integrity and corruption risks in water service delivery in Kenya and Ghana." International Journal of Water Governance 4(11): 3-4. http://www.ijwg.eu/pub/2/.

Berdyaev, N. A. 1918 [2008]. "The psychology of the Russian people: The soul of Russia." In The Fate of Russia, Sect.1, Ch. 1. Moscow: Frsj Publications.

Berry, E., and A. M. Nichols. 2019. "Special issue introduction: Mountains and sacred landscapes." Journal for the Study of Religion, Nature and Culture 13, no. 2: 127-129.

Bischof, M. 2007. "Vernadsky's Noosphere and Slavophile Sobornost." In Biophotonics and coherent systems in biology, eds L. V. Beloussov, V. L. Voeikov, and V. S. Martynyuk, 279-297. New York: Springer.

Bohle, M., and R. Preiser. 2019. "Exploring societal intersections of geoethical thinking." In Exploring geoethics, ed. M. Bohle, 71-136. Cham, Switzerland: Palgrave Pivot.

Bourdieu, P., and J. C. Passeron. 1978. "Reproduction in education, society and culture." Comparative Education 14, no. 1: 75-82. 
Burgui, M. 2011. Ética medioambiental: responsabilidad y derechos. [Environmental ethics: responsibility and rights] Spain: Bubock.

Burgui, M., and E. Chuvieco. 2017. Dimensiones eticas en los dilemas ambientales. Estudios de casos [Ethical dimensions in environmental dilemmas: Case studies]. Madrid: Ediciones Internacionales Universitarias SA.

Carson, D. 2009. "The abduction of Sherlock Holmes." International Journal of Police Science and Management 11, no. 2: 193-202. DOI: 10.1350/ ijps.2009.11.2.123.

Chryssavgis, J., and B. V. Foltz, eds. 2013. Toward an ecology of transfiguration: Orthodox Christian perspectives on environment, nature, and creation. New York: Fordham University Press.

Cohen-Shacham, E., A. Andrade, J. Dalton, N. Dudley, M. Jones, C. Kumard, S. Maginnis, S. Maynard, C. R. Nelson, F. G. Renaud, R. Welling, and G. Walters. 2019. “Core principles for successfully implementing and upscaling nature-based solutions." Environmental Science and Policy 98: 20-29.

Daly, H. E. 1987. "The economic growth debate: What some economists have learned but many have not." Journal of Environmental Economics and Management 14(4): 323-336.

De Unamuno, M. 1902. En torno al casticismo [Around traditionalism]. Madrid: Espasa Calpe, S.A.

Delgado, J. C. 2010. “El problema de la especialización en José Ortega y Gasset: Misión de la Universidad y la rebelión de las masas" [The problem of specialization in José Ortega y Gasset: Mission of the university and the rebellion of the masses]. Paper presented at XLVII Congreso de Filosofía Joven, Universidad de Murcia, April 28-30. http://congresos.um.es/ filosofiajoven/filosofiajoven2010/paper/viewFile/7151/6871.

Di Capua, G., and S. Peppoloni. 2019. “Defining geoethics.” International Association for Promoting Geoethics. http://www.geoethics.org/definition.

Dougherty, M. L. 2019. "Boom times for technocrats? How environmental consulting companies shape mining governance." Extractive Industries and Society 6(2): 443-453.

Dutschke, Rudi. 1980. Mein langer Marsch: Reden, Schriften und Tagebücher aus zwanzig Jahren [My long march: Speeches, writings and diaries from twenty years]. Hamburg: Rowohlt.

Eliade, M. 1959. The Sacred and the profane: The nature of religion. Trans. W. Trask. London: Harcourt Brace Jovanovich.

Ellul, J. 1980. "The ethics of nonpower." In Ethics in an age of pervasive technology, ed. M. Kranzberg, 204-212. New York: Routledge. DOI: https://doi.org/ $10.4324 / 9780429051692$.

Étienne, M. 2010. La modélisation d'accompagnement: une démarche participative en appui au développement durable [Companion modeling: A participatory approach to support sustainable development]. Versailles Cedex, France: Éditions Quæ. 
Falck, W. E. 2016. “Social licencing in mining-between ethical dilemmas and economic risk management." Mineral Economics 29: 97-104.

Francis. 2015. Laudato Si': On Care for Our Common Home. Rome: The Vatican.

Frank, S. L. [1930] 1987. The spiritual foundations of society. Athens: Ohio University Press.

Franklin, S., and E. Widdis, eds. 2004. National identity in Russian culture: An introduction. New York: Cambridge University Press.

Fuchs, C. 2019. "Henri Lefebvre's theory of the production of space and the critical theory of communication." Communication Theory 29(2): 129-150.

Galleni, L., and F. Scalfari. 2005. "Teilhard de Chardin's engagement with the relationship between science and theology in light of discussions about environmental ethics." Journal for the Study of Religion, Nature and Culture, Ecotheology 10, no. 2: 196-214.

Gampel, E. H. 2005. "A framework for moral reasoning." In Moral dilemmas in community health care; cases and commentaries, ed. B. C. White and J. A. Zimbelman, 1-17. New York: Pearson/Longman.

Glenna, L. 2010. "Value-laden technocratic management and environmental conflicts: The case of the New York City watershed controversy." Science, Technology, E Human Values 35, no. 1: 81-112.

Golembiewski, J. 2010. Start making sense: Applying a salutogenic model to architectural design for psychiatric care. Facilities 28(3/4): 100-117.

Government of the Chelyabinsk Region. 2007. "On the approval of the regulation on the monument of nature of the Chelyabinsk region Lake Turgoyak." Document number: 62-П. http://docs.cntd.ru/document/499507759.

Grigoriev, S., and J. Vasina. 2010. "Megaliths of the Vera Island in the Southern Urals." In Proceedings of the XV World Congress of the International Union for Prehistoric and Protohistoric Sciences, Session C68 (Part II). Lisbon, September 4-9, 2006. Oxford: British Archaeological Reports, Vol. 8.

Groenfeldt, D. 2016. “Toward a new water ethic." Leopold Outlook 16, no. 1: 12-16.

Haliy, I. A. 2001. "History of the development of ecological nongovernmental organizations in Russia." In Proceedings of a Workshop: The Role of Environmental NGOs: Russian Challenges, American Lessons. Washington, DC: National Academy Press. https://www.nap.edu/read/10240/chapter/4.

Healing Earth. 2021. International Jesuit ecology project. Chicago: Loyola Chicago University. https://healingearth.ijep.net.

Houet, T., and F. Gourmelon. 2014. "La géoprospective-Apport de la dimension spatiale aux démarches prospectives." [Geoprospective - Contribution of the spatial dimension to prospective approaches] Cybergeo: European Journal of Geography. http://journals.openedition.org/cybergeo/26194.

James, S. P. 2019. "Natural meanings and cultural values." Environmental Ethics 41, no. 1: 3-16.

Jesuit Social Services. 2018. Ecological justice: Expanding the conversation. https:// jss.org.au/ecological-justice-expanding-the-conversation/. 
Josephson, P., N. Dronin, A. Cherp, R. Mnatsakanian, D. Efremenko, and V. Larin. 2013. An environmental history of Russia. New York: Cambridge University Press; Russian Academy of Sciences.

Khairullina, E. R., L. Y. Makhotkina, A. P. Svetlakov, E. D. Emelina, I. V. Vyatkina, I. A. Lipatova, A. A. Pavlushin, and E. A. Sorokoumova. 2019. "Noosphere concept implementation in methodology of modern ecologically oriented higher education: Theoretical aspect." Ekoloji 28 (107): 713-720.

Knott, D., S. Muers, and S. Aldridge. 2008. Achieving culture change: A policy framework. London: Cabinet Office.

Kooiman, J., M. Bavinck, R. Chuenpagdee, R. Mahon, and R. Pullin. 2008. "Interactive governance and governability: An introduction." Journal of Transdisciplinary Environmental Studies 7, no. 1: 1-11.

Kornilova, T. 2006. Turgoyachi. Miass: Geotour.

Korobova, E., and S. Romanov. 2014. "Ecogeochemical exploration of noosphere in light of ideas of V.I. Vernadsky." Journal of Geochemical Exploration 147 (Part A): 58-64.

Kortetmäki, T. 2017. "Justice in and to nature: An application of the broad framework of environmental and ecological justice." PhD diss., University of Jyväskylä.

Kovel, J. 2007. The enemy of nature: The end of capitalism or the end of the world? 2nd ed. London: Zed Books.

Kuhn, T. 1970. The structure of scientific revolutions. 2nd ed. Chicago: Chicago University Press.

Küng, H. 1991. Global responsibility: In search of a new world ethic. London: SCM Press.

Kurlyandskaya, G., and N. Golovanova. 2012. "Environmental protection in the Russian Federation: Assignment of powers." Paper presented at the International Conference on Strengthening Green Federalism, New Delhi, October 2012.

Lagunov A. V. 2004. "The current ecological state of the administrative territory of Miass. City of the Golden Valley." The history of environmental crises in the Southern Urals. Chelyabinsk: YuUTPP, 34-40.

Lagunov, A. 2005. "Main environmental problems of Lake Turgoyak in connection with the development of tourism, sport and recreation." In Proceedings of Lake Turgoyak Sport, Tourism, Ecology, Recreation. Materials of the Scientific and Practical Conference, 20-29, Chelyabinsk.

Lagunov, A. V. 2008. "Lake Turgoyak: The long waiting happy end." Southern Urals in the fate of Russia: History and modernity. Chelyabinsk. Press-master 333-341.

Lagunov, A. V. 2019. "Prospects for the creation of the natural park 'Turgoyak': Natural and cultural heritage of the Urals." In Proceedings of the Scientific Practical Conference, 14-21. Chelyabinsk: ChGIK. 
Laruelle, M. 2017. “L'idéologie comme instrument du soft power Russe. Succès, échecs et incertitudes" [Ideology as an instrument of Russian soft power: Successes, failures and uncertainties]. Hérodote 3-4, no. 166-167: 23-35. https://www.cairn.info/revue-herodote-2017-3-page-23.htm.

Lefebvre, H. 1991. The production of space. Malden, MA: Blackwell.

Levit, G. S. 2000. "Biosphere and the noosphere theories of V.I. Vernadsky and P. Teilhard De Chardin: A methodological essay." Academe Internationale D'histoire des Sciences 50, no. 144: 160-177.

Lorenzo, A. 2006. "Aspectos generales de la geografía cultural” [General aspects in cultural geography]. Autonomous University of Madrid (UAM) https:// www.uam.es/proyectosinv/cotapata/gsocial/\#Geografiacuteacultural.

Machado, A. 1912. Campos de Castilla [Castile fields]. Madrid: Letras Hispanicas. Margenot, M. R. 2009. "Intrahistoria en Unamuno e intratiempo en Machado." [Intra-story in Unamuno and infra-time in Machado]. Speculum: Journal of Literary Studies 42. http://www.ucm.es/info/especulo/numero42/ intrahis.html.

Marone, E., and S. Peppoloni. 2017. "Ethical dilemmas in geosciences. We can ask, but, can we answer?" Annals of Geophysics 60: 1-6.

Maturana, H., and F. Varela. 1984. El árbol del conocimiento[Tree of Knowledge: The Biological Roots of Human Understanding]. Santiago de Chile: Editorial Universitaria.

McIntosh, A., and M. Carmichael. 2016. Spiritual activism: Leadership as service. Cambridge: Green Books.

Melloni, J. 2012. Hacia un tiempo de sintesis.[towards a time of synthesis] Barcelona: Fragmenta Editorial.

Milosevich-Juaristi, M. 2018. El Regimiento Inmortal: orgullo y prejuicio de Rusia. [The Immortal Regiment: The pride and prejudice of Russia]. Madrid Spain: Real Instituto Elcano.

Moiseev, N. N. 1989. "The study of the noosphere-Contemporary humanism." International Social Science Journal 122: 595-606.

Moltmann, J. 1967. Theology of hope: On the ground and the implications of a Christian eschatology. London: SCM.

Montevecchio, C. A. 2017. "Silence." Journal of Religion E Film 21, no. 1. https:// digitalcommons.unomaha.edu/jrf/vol21/iss1/26.

Nasr, S. H. 1997. Man and nature. Chicago: ABC International Group.

Newell, J. P., and L. A. Henry. 2017. "The state of environmental protection in the Russian Federation: A review of the post-Soviet era." Eurasian Geography and Economics 57, no. 6: 779-801.

Nikitina, N. 2014. "Mineral resource dilemma: How to balance the interests of government, local communities and abiotic nature." International Journal of Environmental Research and Public Health 11, no. 9: 8632-8644.

Nikitina, N. 2016. Geoethics: Theory, principles, problems. 2nd ed. Moscow: Geoinformmark. 
Nordblad, J. 2014. "The future of the noosphere." Forum Interdisziplinäre Begriffsgeschichte (FIB) 3 (2): 33-42.

Obolevitch, T., and P. Rójek, eds. 2014. Religion and culture in Russian thought: Philosophical, theological and literary perspectives. Kraków, Poland: Pontifical University of John Paul II.

Oldfield, J., and J. B. Shaw. 2013. "V.I. Vernadskii and the development of biogeochemical understandings of the biosphere, c.1880s-1968." British Journal for the History of Science 46, no. 2: 287-310.

Peppoloni, S., and G. Di Capua. 2015. "The meaning of geoethics." In Geoethics: Ethical challenges and case studies in earth science, ed. M. Wyss and S. Peppoloni, 3-14. Waltham, MA: Elsevier.

Peppoloni, S., N. Bilham, and G. Di Capua. 2019. "Contemporary geoethics within the geosciences." Pp. 25-70 in Exploring geoethics,, ed. M. Bohle. Cham: Palgrave Pivot.

Postman, N. 1993. Technopoly: the surrender of culture to technology. New York: Vintage Books.

Panikkar, R (1999). The intrareligious dialogue. New Jersey Paulist Press

Prada-Rodríguez, M. L. 2019. “¿Orientan los aparatos tecnológicos las acciones humanas? Una postura praxeológica." [Do technological devices guide the human actions? A praxeological stance] Trilogía Ciencia Tecnología Sociedad 11, no. 21: 67-89.

Promotio Iustitiae. 2011. Healing a broken world. No. 106, 2011/2 Social Justice Secretariat. www.sjweb.info/sjs/PJnew.

Ramis Pujol, J., M. F. Suárez Barraza, and R. Sardà. 2015. “Socio-ecological spirituality and entrepreneurship: Sa Pedrissa network in Majorca." In Proceedings of Spirituality and Creativity in Management World Congress. ESADE, Barcelona, April 23-25.

Riechmann, J., J. I. González Faus, and C. Magallón. 2019. Wake up! Proposals for a decentred humanism. Barcelona: Christianisme i Justícia.

Rindzevičiūtè, E. 2018. Soviet policy sciences and earth system governmentality. Cambridge: Cambridge University Press.

Robinson, J. M. 2006. The sacred cinema of Andrei Tarkovsky. Maidstone, Kent: Crescent Moon.

Rodríguez, M. L. 2006. Geopoliticaustral espacios, territorios y poder: Algunas categorías del análisis geopolítico [Spaces, territories and power: Some categories of geopolitical analysis]. Punta Arenas: Geopolitica Teorica.

Rolston, H. 1988. Environmental ethics: Duties to and values in the natural world. Philadelphia: Temple University Press.

Rutherford, S. 2017. "Environmentality and green governmentality." Pp. 1-5 in The international encyclopedia of geography, ed. D. Richardson, N. Castree, M. F. Goodchild, A. Kobayashi, W. Liu, and R. A. Marston. Hoboken, NJ: John Wiley \& Sons.

Samoilova, S. 2012. “Turgoyak as a gift of fate.” Vesi 7 (SI): 30-32. http://ukbki.ru/ upload/content/files/vesi-7-pavl-2012-all_low_.pdf. 
Samoilova, S. 2016. “Red Turgoyak.” Ural Stalker 11, no. 713: 30-33. http:// www.uralstalker.com/uarch/us/2016/11/30/.

Samson, P. R., and D. Pitt, eds. 1999. The biosphere and noosphere reader: Global environment, society and change. London: Routledge.

Sementovsky, V. N. 1916. Turgoyak. Kazan: Litho Printing House.

Serafin, R. 1987. “Vernadsky's biosphere, Teilhard's noosphere, and Lovelock's gaia: Perspectives on human intervention in global biogeochemical cycles." IIASA Working Paper WP-87-096, Laxenburg, Austria.

Seymour, V. 2016. "The human-nature relationship and its impact on health: A critical review." Frontiers in public health 4: 260. DOI: 10.3389/ fpubh.2016.00260.

Sheldrake, R. 2012. The science delusion: Feeling the spirit of enquiry. London, UK: Coronet.

Sikorskaya, G. P., O. B. Akimova, E. M. Dorozhkin, and I. V. Yakhneeva. 2016. "Noospheric pedagogy: The expansion of the humanitarian space of vocational and pedagogical education." International Journal of Environmental E Science Education 11, no. 14: 6963-6975.

Soja, E. W. 2010. Seeking spatial justice. Minneapolis: University of Minnesota Press.

Taylor, B. 1995. Ecological resistance movements. The global emergence of radical and popular environmentalism. Albany: State University of New York Press.

Taylor, B. 2009. Dark green religion: Nature spirituality and the planetary future. Berkeley: University of California Press.

Teilhard de Chardin, P. 1956. "The antiquity and world expansion of human culture." In Man's role in changing the face of the Earth, ed. W. L. Thomas, Jr., Vol. 1, 103-112. Chicago: University of Chicago Press.

Tischner, J. 2005. Selected by Dobrosław Kot from Etyka solidarności [The Ethics of Solidarity]. Kraków. http://www.tischner.org.pl/content/images/ tischner_4_ethics_years_later.pdf.

Tishkov, V. 2008. The Russian people and national identity. Moscow, Russia: Russia in Global Affairs. No 3. https://eng.globalaffairs.ru/number/n_11287.

Tkachev, B. A., A. G. Rogozin, S. V. Gavrilikina, B. A. Mironov, N. S. Gordienko, D. V. Mityuhlyaev, T. F. Krivopalova, and G. V. Tanayeva. 1997. The status of ecosystems of Lake Turgoyak: Problems of ecology and environmental education in the Chelyabinsk region. IGZ UB RAS, Miass, Russia, 64-65.

Torretta, G. 2015. “Thomas' green thumb: Ecotheology beyond revolution and reform." Angelicum 92, no. 2: 213-232.

Touraine, A. 1980. "The voice and the eye: On the relationship between actors and analysts." Political Psychology 2, no. 1: 3-14.

Tsepaeva, E. 2011. History of the village Turgoyak. Miass: Miass College of Arts and Culture.

UNU. 2007. "Perspectives on social vulnerability." Source Studies of the University: Research, Counsel, Education. Publication Series of UNU-EHS No. 6/2007, ed. K. Warner. Bonn: UNU-EHS. 
Vernadsky, V. I. 1945. “The biosphere and noosphere." American Scientist 33, no. 1: 1-12.

Vernadsky, V. 2012. "The transition from the biosphere to the noösphere. Excerpts from scientific thought as a planetary phenomenon (1938)." In 21st Century Science \& Technology (Spring-Summer). www.21stcenturysciencetech.com.

Vernadsky, V. I. (1998 [1926]) The Biosphere. New York: Copernicus.

Voiron, C. 2012. "L'anticipation du changement en prospective et des changements spatiaux en géoprospective. [The anticipation of change in prospective and spatial changes in geoprospective.] " L'Espace Géographique 41, no. 2: 99-110.

Weisberg, E. I., and V. D. Zakharov. 2001. Wildlife of the Miass Valley: A manual for teachers and students. Miass: Geotour.

Westbroek, P. 1991. Life as a geological force: Dynamics of the Earth. New York: Norton.

Williams, R. S., Jr., and J. G. Ferrigno, eds. 2012. State of the Earth's cryosphere at the beginning of the 21st century: Glaciers, global snow cover, floating ice, and permafrost and periglacial environments. U.S. Geological Survey Professional Paper 1386-A, Reston, VA.

Wyndham, F. S. 2000. "The sphere of the mind: Reviving the noösphere concept for ecological anthropology." Journal of Ecological Anthropology 4, no. 1: 87-91.

Yanitsky, O. N. 2018a. "The development of the Russian environmental movement in the beginning of XXI century." International Journal of Humanities Social Sciences and Education 5, no. 6: 23-31.

Yanitsky, O. N. 2018b. "Ecology as a global geopolitical issue." International Journal of Political Science 4, no. 1: 43-52.

Yanitsky, O. N. 2020. "The ecological wars: The notion, concept and dynamics." Advances in Social Sciences Research Journal 7, no. 6: 477-488.

Žižek, S. 1989. The sublime object of ideology. London: Verso. 